\title{
OBRAZ STANÓW ZJEDNOCZONYCH AMERYKI W LATACH SIEDEMDZIESIĄTYCH XIX WIEKU W LISTACH Z PODRÓŻY DO AMERYKI HENRYKA SIENKIEWICZA
}

Stany Zjednoczone Ameryki jako kraj od ponad 150 lat będący jednym z głównych celów polskiej emigracji, stał się tematem wielu opracowań i relacji napisanych przez odwiedzających go Polaków. Wśród nich na uwagę zasługują Listy z podróży do Ameryki autorstwa Henryka Sienkiewicza, które stanowią dobre źródło historyczne ukazujące realia panujące w tym kraju w epoce pozłacanego wieku, jak też sposób postrzegania go przez Polaków. Celem niniejszego artykułu jest analiza obrazu Stanów Zjednoczonych sporządzonego przez pisarza w momencie istotnym dla historii Polonii amerykańskiej - początkowej fazie masowej emigracji Polaków do Ameryki.

Henryk Sienkiewicz przybył do Stanów Zjednoczonych w marcu 1876 roku. Jego celem podróży było miasto Anheim w Kalifornii, gdzie wraz z grupą przyjaciół miał założyć falanster na wzór Brook Farm ${ }^{1}$ i zamieszkać w nim na stałe. Jak pisała Helena Modrzejewska w swoich wspomnieniach, Sienkiewicz jako pierwszy opowiedział się za emigracją zaproponowaną przez męża aktorki². Powodem tej decyzji miało być poszukiwanie nowego stylu życia, bez różnego rodzaju ograni-

Mgr Maria ANNA FurTaK - doktorantka, Instytut Historii na Wydziale Nauk Humanistycznych KUL; e-mail: furtakma@gmail.com

${ }^{1}$ Brook Farm - założona w 1841 roku na przedmieściach Bostonu przez Georga Ripleya społeczność o charakterze utopijnym, na bazie idei transcendentalizmu. Celem jej działalności było zaproponowanie nowego (opozycyjnego do kapitalizmu) stylu życia, opartego na równości wszystkich członków, połączeniu pracy fizycznej z intelektualną, por. J. HerLiny, Brook Farm, Massachusetts 1841-45: A Transcendental Tourist Trap, „Cercles” 30(2013), s. 65-76.

${ }^{2}$ H. Modrzejewska, Memoirs and Impressions of Helena Modjeska. An Autobiography, New York 1910, s. 248. 
czeń ideowych, wynikające z niechęci do sytuacji politycznej znajdujących się pod zaborami ziem polskich (prześladowania polskich patriotów, polityka germanizacji i rusyfikacji), rozczarowania niepowodzeniami programu pozytywistów, chęć polepszenia statusu materialnego, a także ucieczka od środowiska nieżyczliwych osób ${ }^{3}$.

Pisarz w podróż wyruszył na parowcu Germanicus z portu w Liverpoolu, w towarzystwie Juliusza Sypniewskiego (przyjaciela Chłapowskiego), zaś pozostali, to jest Helena Modrzejewska z mężem, Karolem Chłapowskim, i synem Rudolfem ${ }^{4}$, Lucjan Paprocki, karykaturzysta, oraz rodzina Sypniewskiego dołączyli do niego kilka miesięcy później ${ }^{5}$. Na amerykańskiej ziemi przebywał przez dwa lata ${ }^{6}$, zdając relacje z tego pobytu w artykułach (m.in. Szkice amerykańskie, Osady polskie w Stanach Zjednoczonych, Chinczycy w Kalifornii) publikowanych w „Gazecie Polskiej”, „Kurierze Codziennym” i „Przeglądzie Tygodniowym” w latach 1876-18787, wydanych potem jako Listy z podróży do Ameryki ${ }^{8}$. W swoich opisach pisarz starał się być obiektywny, wielokrotnie dementując stereotypy i „fałszywe wyobrażenia” ${ }^{\text {na }}$ temat Stanów Zjednoczonych krążące w świadomości Europejczyków, jak również poddając rewizji swoje wcześniejsze opinie dotyczące tego kraju ${ }^{10}$.

Stany Zjednoczone w czasach Sienkiewicza były relatywnie młodym państwem, w roku 1876 obchodzące 100-lecie istnienia, dopiero rozwijającym się, ale zwiastującym już perspektywy na gigantyczny sukces i aspirującym do roli lidera światowego. W tym czasie (od 10 maja do 10 listopada 1876 roku) w Filadelfii zorganizowano Światową Wystawę (The Centennial International Exposition), mającą upamiętnić wiek istnienia Stanów Zjednoczonych, a także przedstawić tamtejsze osiaggnięcia techniczne (m.in. telefon Alexandra G. Bella czy silnik parowy Corlissa) ${ }^{11}$. Europejczycy postrzegali ten kraj jako miejsce atrakcyjne gospodarczo

${ }^{3}$ Z. NAJder, Przedmowa, w: H. Sienkiewicz, Listy z podróży do Ameryki, Warszawa 1956, s. 6-9; H. ModrzejewsKa, Memoirs: "My desire was to get away from Warsaw and the unfriendly spirits as soon as possible" (s. 247).

${ }^{4}$ Rudolf Modrzejewski/Ralph Modjeski (1861-1940) - polsko-amerykański inżynier i budowniczy mostów, uznany za jednego z najwybitniejszych specjalistów w tej dziedzinie, autor wielu publikacji naukowych i budowniczy ponad 30 mostów w Stanach Zjednoczonych.

${ }^{5}$ H. ModrzejewsKa, Memoirs, s. 249-251.

${ }^{6}$ E.B. Warych, Sienkiewicz's Sojourn in America, „Polish American Studies” 15(1958), nr 3-4, s. $65-67$.

${ }^{7}$ M. Nobilis, Sienkiewicz and the Poles in America, „Polish American Studies” 2(1945), nr 1-2, s. 34 .

${ }^{8}$ Pierwsze wydanie w 1880 roku w Warszawie: Pisma Henryka Sienkiewicza: Listy z podróży po Ameryce, t. II, Warszawa 1880.

${ }^{9}$ H. Sienkiewicz, Listy z podróży do Ameryki, Warszawa 1956, s. 147.

${ }^{10}$ Por. tamże, s. 58 i 601.

${ }^{11}$ D.E. SHI, Narodziny realizmu: myśl i kultura amerykańska 1865-1900, w: Historia Stanów Zjednoczonych, t. III: 1848-1917, red. W. Nugent, H. Parafianowicz, Warszawa 1995, s. 218. 
(„gorączka złota”, dostępność tanich gruntów i miejsc pracy), politycznie (jako ideał demokracji), oferujące wolność oraz szerokie możliwości rozwoju ${ }^{12}$. W świadomości Polaków ponadto funkcjonowały wspomnienia o osiągnięciach i czynach Pułaskiego i Kościuszki z czasów wojny o niepodległość, a aurę niezwykłości tego kraju podsycała literatura, głównie dzieła Jamesa Fenimore’a Coopera oraz reklamy przewoźników transatlantyckich ${ }^{13}$.

Unia liczyła wtedy jedynie 37 stanów położonych na Wschodnim Wybrzeżu, środkowym wschodzie, Południowym i Zachodnim Wybrzeżu, a w roku przybycia Sienkiewicza dołączono do niej stan Kolorado. Szybko postępujące industrializacja i urbanizacja doprowadziły do powstania wielkich miast, takich jak Chicago, Cincinatti, Baltimore, St. Louis, Filadelfii i Bostonu, zaś budowa sieci kolejowej oraz odkrycie złóż metali szlachetnych - do kolonizacji położonych na zachód od rzeki Missisipi Wielkich Równin i Kordylierów. Oprócz tego, miał miejsce postęp w amerykańskim rolnictwie, jak też rozwój nowych technologii produkcji czy przedsiębiorstw usługowych ${ }^{14}$. Wszystkie te czynniki spowodowały wzrost koniunktury, stawiając kraj wśród czołówki gospodarek światowych i zapoczątkowując tzw. gilded age - wiek pozłacany w historii amerykańskiej (1870-1900).

Pierwsze zetknięcie Sienkiewicza ze Stanami Zjednoczonymi nastąpiło w Nowym Jorku, mieście-symbolu tego kraju. Było to miejsce kosmopolityczne, pełne skrajności, wolności, tolerancji, zamieszkałe przez dziesiątki tysięcy przedstawicieli różnych narodowości i wyznań, oferujące możliwości każdemu przybyszowi, ale pozbawione historii ${ }^{15}$. Handel był podstawą funkcjonowania Nowego Jorku, w którym z uwagi na położenie na wyspie brakowało miejsca na rozwój sektora przemysłowego. Dlatego też krajobraz miasta w dużej mierze stanowiły giełdy, banki, sklepy, domy handlowe. Oprócz tego, kwitła produkcja manufakturowa, stawiając Nowy Jork na pierwszym miejscu produkcji tego typu w kraju ${ }^{16}$. Przodującą rolę miasta $\mathrm{w}$ dziedzinie handlu podnosił jeszcze fakt posiadania portu, co przyznał sam Sienkiewicz pisząc, iż Nowy Jork ma większy potencjał na rozwój od miast europejskich ${ }^{17}$. Było to też miejsce, w którym kończyła się transatlantycka podróż wielu przybyszów z Europy, a zaczynało życie imigranta. W położonym

\footnotetext{
12 J. Swastek, Polish Travelers in Nineteenth Century United States, „Polish American Studies” 2(1945), nr 1-2, s. 38.

${ }^{13}$ F. STASIK, Polska emigracja zarobkowa w Stanach Zjednoczonych Ameryki 1865-1914, Warszawa 1985, s. 51; H. SienKiewicz, Listy, s. 176, 186, 598.

14 D.R. GoldField, Rozwój miast i przemystu w latach 1850-1920, w: Historia Stanów Zjednoczonych, t. III, s. 154-158, 166.

${ }^{15}$ A. Muhlstein, Manhattan. Niezwykta historia Nowego Jorku od czasów Indian do roku 2000, tłum. K. Osińska-Boska, Warszawa 1994, s. 144; H. Sienkiewicz, Listy, s. 119.

16 A. Muhlstein, Manhattan, s. 130-31.

17 H. Sienkiewicz, Listy, s. 122.
} 
na Manhattanie forcie Castle Garden znajdowała się pierwsza w amerykańskiej historii stacja rejestrująca imigrantów (1855-1890, potem stację przeniesiono na Ellis Island), czasem poddająca ich kwarantannie i decydująca przede wszystkim o możliwości pozostania ich na terenie kraju ${ }^{18}$.

Innym wielkim miastem - reprezentantem ówczesnych Stanów Zjednoczonych, które rozwinęło się dzięki industrializacji, było Chicago. W czasie podróży Sienkiewicza odbudowywano je po pożarze, który w 1871 roku zniszczył jedną trzecią jego powierzchni, pozbawiając dachu nad głową 100 tysięcy ludzi oraz przynosząc straty szacowane na 200 milionów dolarów. Paradoksalnie, pożar nie zahamował rozwoju miasta, ponieważ główne ośrodki przemysłowe nie znalazły się na jego drodze, zaś konieczność odbudowy spalonej części Chicago była czynnikiem motywującym i doprowadzającym do jego rozkwitu ${ }^{19}$.

Rozwijał się tam bowiem przemysł hutniczy i stalowy, którego głównym udziałem była produkcja szyn kolejowych ${ }^{20}$. Ponadto w mieście funkcjonowały największe rzeźnie i zakłady przetwórstwa mięsnego w kraju zrzeszone w Union Stock Yards, które zdobyły monopol, dzięki sprawnemu przesyłaniu produktów możliwemu przez zlokalizowaną w ich pobliżu sieć połączeń kolejowych i zastosowanie nowej technologii, jaką było mrożenie żywności ${ }^{21}$.

Istnienie wielkich zakładów przemysłowych oraz towarzyszących im przedsiębiorstw przyciągało wielu imigrantów poszukujących pracy, głównie Irlandczyków, Niemców, Włochów, znaczną grupę pośród nich stanowili Polacy. Pod koniec lat 60. XIX wieku rozpoczęło się formowanie społeczności polskiej w Chicago. O tym, jak dynamiczne było to zjawisko, świadczy fakt, iż w czasie, gdy Sienkiewicz odwiedzał miasto, żyło w nim 20 tysięcy Polaków ${ }^{22}$, funkcjonowały trzy polskie parafie (św. Stanisława Kostki, Świętej Trójcy, św. Wojciecha) ${ }^{23}$, działały polskie księgarnie ${ }^{24}$, przedsiębiorstwa prowadzone przez Polaków ${ }^{25}$, towarzystwa religijne ${ }^{26}$, wydawano tygodniki: „Gazeta Polska” (1873), „Tygodnik Literacko-

18 F. Stasik, Polska emigracja zarobkowa, s. 57-8; H. Sienkiewicz, Listy, s. 112-114.

19 D.A. PaCyga, Chicago. A Biography, Chicago 2009, s. 77-83.

20 D. Bensman, M.R. Wilson, Iron and Steel, w: Encyclopedia of Chicago, http://www.encyclopedia. chicagohistory.org/pages/653.html [dostęp:12.02.2018].

${ }^{21}$ J.R. Barrett, Chicago Neighborhoods and Suburbs. A Historical Guide, red. A.D. Keating, s. 103; D.A. PaCYGa, Chicago, s. 60-65.

${ }^{22}$ M. Haiman, Poles of Chicago, w: Poles of Chicago 1837-1937. A History of one Century of Polish Contribution to the City of Chicago, Illinois, Chicago 1937, s. 4; H. SiENkIEwICZ, Listy, s. 572.

${ }^{23}$ Polish Churches in Chicago and Vicinity, w: Poles of Chicago, s. 96-98.

${ }^{24}$ H. Sienkiewicz, Listy, s. 577.

25 T. Lumbera, Hundred Years of Economic Contribution of the Poles to Chicago's Progress, w: Poles of Chicago, s. 13.

${ }^{26}$ H. Sienkiewicz, Listy, s. 572. 
-Naukowy” (1873), „Gazeta Polska Katolicka” (1874) ${ }^{27}$. Z inicjatywy Zgromadzenia Księży Zmartwychwstańców w 1873 roku powstało Zjednoczenie Polskie Rzymsko-Katolickie, jedna $\mathrm{z}$ czołowych organizacji polonijnych w tym kraju, oferująca pomoc potrzebującym rodakom ${ }^{28}$.

Rozbudowana sieć kolejowa otaczająca Chicago, umożliwiała nie tylko transport towarów, ale również sprawną komunikację miasta $\mathrm{z}$ resztą kraju, przede wszystkim z Detroit, Cleveland czy położonym na zachodzie Omaha ${ }^{29}$. Stanowiła fragment „kolei Dwóch Oceanów”, pierwszej transkontynentalnej linii łączącej oba wybrzeża Stanów Zjednoczonych (First Trans Continental Road). Jej trasa przebiegała przez stany: Michigan, Iowa, Nebraska, Wyoming, Utah, Nevada, aż po San Francisco w Kalifornii. Ukończono ją w 1869 roku $^{30}$, a Sienkiewicz miał być pierwszym Polakiem, który zrelacjonuje podróż tą liniąa ${ }^{31}$. Powstanie kolei okazało się punktem zwrotnym w historii Stanów Zjednoczonych, kluczowym czynnikiem dla ich rozwoju ekonomicznego i postępującej industrializacji, ponieważ ułatwiło, a także znacznie przyspieszyło kolonizację Zachodu, transport ludzi i towarów, który dotychczas opierał się na tradycyjnych i czasochłonnych jego formach, $\mathrm{tj}$. zaprzęgach konnych ${ }^{32}$.

Jak wynika z obserwacji pisarza, gęstość zaludnienia nie rozkładała się równomiernie na terenie kraju, po którym podróżowal ${ }^{33}$. Regiony wschodnie, z Nowym Jorkiem na czele, cechowało przeludnienie, z uwagi na żyzność terenów umożliwiającą intensyfikację rolnictwa, rozwijający się przemysł i handel, oraz bliskość portów łączących Stany Zjednoczone z Europą, w pobliżu których masowo osiedlali się imigranci niepotrafiący poradzić sobie w nowych okolicznościach, o których sytuacji wspomniał Sienkiewicz w swoich relacjach, a także opisał w noweli $Z a$ chlebem $^{34}$. Podobne zjawisko miało miejsce na wybrzeżu kalifornijskim, które stało się celem rzesz chińskich imigrantów ${ }^{35}$.

$\mathrm{Z}$ drugiej strony, olbrzymie terytoria pozostawały niezamieszkałe, były to tereny położone na Dalekim Zachodzie (Far West), tj. na zachód od rzeki Missisipi, w rejonie Wielkich Równin i Gór Skalistych czy Sierra Nevada, trudnych do okiełznania

${ }^{27}$ H. Chrzanowska, Sixty-four Years of Polish Book Publishing in Chicago, w: Poles of Chicago, s. 189.

${ }^{28}$ M. Haiman, Poles of Chicago, s. 6.

29 J.C. Hudson, Railroads, w: Encyclopedia of Chicago, http://www.encyclopedia.chicagohistory. org/pages/1039.html [dostęp: 12.02.2018].

30 P.N. Limerick, Amerykański Zachód 1848-1917, w: Historia Stanów Zjednoczonych, s. 107-108.

${ }^{31}$ H. SiENKIEwicz, Listy, s. 151.

32 P.N. Limerick, Amerykański Zachód, s. 104-107.

${ }^{33}$ H. Sienkiewicz, Listy, s. 603-605.

34 Tamże, s. 128.

35 Tamże, s. 603. 
przez człowieka, atrakcyjnych jednak ze względu na złoża szlachetnych kruszców. Gorączka złota, która wstrząsnęła Kalifornią pod koniec lat 40. XIX wieku, dawała o sobie znać również w czasach, kiedy w USA przebywał Sienkiewicz ${ }^{36}$. Jak pisał w Listach, w czasie podróży widział poszukiwaczy złota, którzy na wieść o odkryciu nowych złóż masowo zmierzali do położonego nieopodal Gór Skalistych pasma Black Hills ${ }^{37}$. W innej relacji podał, iż na terenach pomiędzy Dakotą a Wyoming liczba poszukiwaczy złota dochodziła do 30 tysięcy $^{38}$. Stwierdził, iż bogactwo złóż naturalnych doprowadziło do powstania wielu miast w Kalifornii, takich jak San Francisco, Sacramento, Virginia City, a na jego oczach budowano kolejne - Darwin ${ }^{39}$.

W innej relacji Sienkiewicz opisał zajmujące olbrzymie połacie Dalekiego Zachodu prerie, dobrze oddając charakter panoramy kolonizowanych dopiero terenów: „Pustynia nie jest tak bezludna, jak się na pierwszy rzut oka wydaje. Prócz skwaterów włóczą się po niej traperowie, to jest ludzie robiący sobie rzemiosło z polowania i awantur; wakerosi, to jest strażnicy stad lub karawan kupieckich; prości drapichrustowie, czasem górnicy, a na koniec, w periodzie wędrówek bawołów, większe i mniejsze oddziały Indian polujących na te zwierzęta, a gdzie się da, i na skalpy" "40. Daleki Zachód był więc miejscem pełnym dynamizmu, sceną nieustających wędrówek, walk o przetrwanie, starć cywilizacji z naturą, symbolizując szybko rozwijające się Stany Zjednoczone.

Sienkiewicz spędził jako osadnik w Górach Santa Ana kilka miesięcy ${ }^{41}$. Dość obszernie opisał mechanizm zasiedlania dzikich terenów przez pionierów, których nazywa „skwaterami” (od squatter - osadnik nieposiadający prawa do użytkowania danego terenu). Według ówczesnego prawa, każdy obywatel amerykański lub imigrant mógł osiąść na niezajętej dotąd ziemi o powierzchni 160 akrów, która po 10 latach użytkowania stawała się jego własnością ${ }^{42}$. Proces ten wymagał od osadników wykazania się wytrwałością i determinacją, z uwagi na znaczne oddalenie od cywilizacji, brak odpowiednich narzędzi, trudne warunki klimatyczne i zagrożenie ze strony dzikich zwierząt ${ }^{43}$.

Kolejną cechą charakterystyczną dla Stanów Zjednoczonych w XIX wieku, szczególnie w drugiej jego połowie była imigracja. Miała ona zupełnie inny

\footnotetext{
${ }^{36}$ P.N. Limerick, Amerykański Zachód, s. 96-98.

${ }^{37}$ H. SienKIEwiCZ, Listy, s. 178.

38 Tamże, s. 489.

39 Tamże, s. 518.

40 Tamże, s. 305.

${ }^{41}$ Tamże, s. 316-350.

42 Tamże, Listy, s. 300; F. Stasik, Polska emigracja zarobkowa, s. 66.

${ }^{43}$ H. Sienkiewicz, Listy, s. 301-305.
} 
charakter, niż podobne zjawisko znane w Europie, ale powodowane czynnikami politycznymi. Industrializacja, a także szerokie możliwości dotyczące osadnictwa i rozwoju zachęcały thumy przybywające z Azji i Europy, nadając imigracji charakter ekonomiczny ${ }^{44}$. Wśród nich znaczącą grupę stanowili Polacy, to właśnie na początek lat 70. XIX wieku datuje się początek ich wzmożonego napływu.

Sienkiewicz pisząc, że „człowiek, który wyjeżdża do Ameryki jest jeszcze u nas rzadkością" ${ }^{45}$, miał na myśli przedstawicieli wyższych warstw społecznych, podczas gdy fala wychodźstwa rozpoczęta w tym czasie dotyczyła przede wszystkim uwłaszczonej ludności chłopskiej. Ze względu na swój ekonomiczny wymiar powodowany biedą, głodem ziemi, bezrobociem, niekorzystną polityką zaborców (pobór do wojska, kulturkampf, germanizacja, rusyfikacja, prześladowania uczestników powstania styczniowego) ${ }^{46}$ oraz reklamowymi akcjami armatorów, określana jest jako emigracja „za chlebem" ${ }^{\text {47 }}$. Szacuje się, że w jej wyniku do końca XIX wieku w Stanach Zjednoczonych osiedliło się milion Polaków ${ }^{48}$. W latach 70. XIX wieku w tym kraju miało przebywać ich około 200-300 tysięcy, sam pisarz stwierdził jednak, że liczby te są celowo zawyżane przez redaktorów polskich tygodników, opisując stan polskiej emigracji w artykule Osady polskie w Ameryce ${ }^{49}$.

Przybywający do Stanów Zjednoczonych Polacy osiedlali się głównie we wschodniej części kraju, w regionach rozwiniętych rolniczo oraz w miastach, gdzie dominował przemysł - w Chicago, Detroit, Cleveland, Buffalo, Pittsburghu. Zatrudnienie znajdowali tam głównie w hutach stali, fabrykach maszyn, we młynach, rzeźniach i zakładach przetwórstwa mięsnego, w kolejnictwie ${ }^{50}$. Polscy imigranci pochodzenia chłopskiego w większości nie posiadali kwalifikacji do wykonywania określonych zawodów, dlatego też podejmowali te najsłabiej płatne prace ${ }^{51}$. Trudnością napotykaną przez nich była bariera językowa, a także nieznajomość realiów społeczno-politycznych panujących w tym kraju.

Cechą charakterystyczną wszystkich grup migrantów było tworzenie etnicznych skupisk $^{52}$. Tak jak Niemcy, Irlandczycy, Włosi czy Chińczycy ${ }^{53}$, również Polacy

44 D.R. Gabaccia, Imigracja do Stanów Zjednoczonych 1848-1917, w: Historia Stanów Zjednoczonych, s. 187-188; H. SiENKIEWICZ, Listy, s. 583.

45 H. Sienkiewicz, Listy, s. 37.

${ }^{46}$ F. Stasik, Polska emigracja zarobkowa, s. 26-32; P. Fox, Poles in America, New York 1922, s. $58-59$.

47 H. Sienkiewicz, Listy, s. 601.

${ }^{48}$ F. STASIK, Polska emigracja zarobkowa, s. 44.

49 H. Sienkiewicz, Listy, s. 570.

50 P. Fox, The Poles in America, s. 62-63.

${ }^{51}$ F. Stasik, Polska emigracja zarobkowa, s. 91.

52 Tamże, s. 84-85.

${ }^{53}$ H. SienKiewicz, Listy, s. 607. 
zwykli zamieszkiwać te same obszary miast lub nawet budować własne miejscowości od podstaw. Sienkiewicz wymienił 44 całkowicie lub w przeważającej części polskie osady istniejące na terenie Stanów Zjednoczonych ${ }^{54}$. Najwięcej powstało ich w stanie Wisconsin ${ }^{55}$, a Sienkiewicz z niechęcią opisał je jako „wioski pod wodzą proboszczów" 56 , mających zbyt duży wpływ na wiernych. W rzeczywistości jednak działania duchownych posługujących wśród polskich imigrantów przyniosły wiele korzyści skupiskom wychodźców, przede wszystkim doprowadziły do pojawienia się polskich etnicznych parafii ${ }^{57}$. Nie były one jedynie ukierunkowane na wspieranie rozwoju duchowego, ale stały się centrami polskości, gdzie kształtował się patriotyzm i narodowa świadomość, kultywowano obyczaje i tradycje przywiezione z Ojczyzny, a przede wszystkim język ${ }^{58}$. Wokół polskich parafii organizowano szkoły, tak zwane instytucje pomocowe i kulturalne, różnego rodzaju przedsiębiorstwa, banki, kasy pożyczkowe. Powstanie tych etnicznych wspólnot było istotnym czynnikiem spajającym i integrującym polskich wychodźców, współdzielących tę samą kulturę, język, religię, sposoby postrzegania świata, wzmacniającym poczucie etnicznej i narodowej przynależności i umożliwiającym formowanie się amerykańskiej Polonii ${ }^{59}$. Sienkiewicz negatywne ocenił grupy polskich wychodźców, krytykując brak ich umiejętności współdziałania i wyrażając obawę o ich rychłe wynarodowienie przez zasymilowanie ze społeczeństwem amerykańskim ${ }^{60}$. Nie jest to zgodne z prawdą, co zresztą przyznał sam pisarz, twierdząc, że dokonał tylko pobieżnego opisu grup Polaków rozsianych po całych Stanach. W rzeczywistości, w grupach przetrwała polskość, kształtowało się poczucie przynależności narodowej, kultywowano tradycje, realizowano cele patriotyczne, co nie było możliwe na ziemiach polskich pod zaborami ${ }^{61}$.

Zainteresowanie pisarza wzbudzili rdzenni Amerykanie znajdujący się w tym czasie w skrajnie trudnej sytuacji. Jako „tubylczy naród zależny”62 pozbawieni byli praw obywatelskich, a nawet praw do życia na własnych terytoriach. Zjawisko przesiedlania ich do rezerwatów, głównie Indian Territory (późniejszy stan Oklahoma), nasiliło się po 1865 roku, wraz z rozwojem przemysłu i rolnictwa,

54 Tamże, s. 547.

55 W. KRUSZKa, Historyja polska w Ameryce: poczatek, wzrost i rozwój dziejowy osad polskich w Pótnocnej Ameryce (Stanach Zjednoczonych i Kanadzie), t. I, Milwaukee 1905, s. 84; H. SiENKIEWICZ, Listy, s. 576.

${ }^{56}$ H. Sienkiewicz, Listy, s. 174.

57 Tamże, s. 585-586.

58 B. Leś, Kościót w procesie asymilacji Polonii amerykańskiej, Wrocław 1981, s. 33.

59 P. Fox, Poles in America, s. 92.

${ }^{60}$ H. Sienkiewicz, Listy, s. 588.

${ }^{61}$ P. Fox, Poles in America, s. 92.

${ }^{62}$ I. Rusinowa, Murzyni i Indianie 1865-1914, w: Historia Stanów Zjednoczonych, s. 135. 
budową linii kolejowych, farm i wypasem bydła na preriach oraz będącym ich następstwem wytępieniem bizonów, zwierząt nieodzownych dla indiańskiego stylu życia $^{63}$. W latach 70. XIX wieku rdzenni Amerykanie żyli już głównie w rezerwatach. Jak relacjonował pisarz, po Indianach pozostały tylko nazwy terenów, które niegdyś do nich należały (np. Jezioro Huron) ${ }^{64}$. Mimo obietnic od rządu gwarantujących niektórym plemionom nienaruszalność ich ziem, biali osadnicy, traperzy, „awanturnicy” - jak określa ich Sienkiewicz - siłą wypędzali z nich rdzennych Amerykanów, w celu pozyskania dostępu do potencjalnie rentownych terenów ${ }^{65}$. Zjawisko to było powodowane przede wszystkim przez gorączkę złota i srebra. Miało miejsce wiele potyczek między broniącymi swoich terytoriów Indianami (m.in. Komanczami, Czejanami) a osadnikami. Doszło do nich m.in. w 1876 roku w następstwie odkrycia złóż złota w Black Hills. Największym tego typu wydarzeniem okazała się bitwa pod Little Big Horn w czerwcu 1876, kiedy Indianie pokonali oddział amerykańskiej armii dowodzony przez generała George'a A. Custera ${ }^{66}$. O tym krwawym wydarzeniu wspomniał pisarz, stwierdzając, iż jest ono wynikiem postępującej cywilizacji ${ }^{67}$. Należy dodać, że niektóre plemiona dobrowolnie ulegały asymilacji ze społeczeństwem amerykańskim, co jednak również skazywało je na zatracenie swojego dziedzictwa ${ }^{68}$.

W korzystniejszej niż Indianie sytuacji znajdowała się ludność murzyńska. Po wojnie secesyjnej zniesione zostało niewolnictwo, Murzyni uzyskali prawa wyborcze, pojawiło się wiele inicjatyw umożliwiających im przystosowanie do funkcjonowania $\mathrm{w}$ amerykańskim społeczeństwie ${ }^{69}$. Szczególnie dobre warunki do życia znajdowali w Nowym Jorku ${ }^{70}$. Z powodu braku wykształcenia i kwalifikacji zmuszeni byli wykonywać najsłabiej płatne prace, w takich też widział ich Sienkiewicz, jako służących, „furmanów, wyrobników, tragarzy towarów”71. Nie żywił jednak do nich sympatii, tak jak do rdzennych Amerykanów, ukazując ich jako ludność niechlujną, niewykształconą, nieokrzesaną a nawet brzydką ${ }^{72}$.

Sienkiewicz położył duży nacisk na opis społeczeństwa, starał się dokładnie opisywać zwyczaje, tak odmienne od europejskich. Szczególnie raził go brak manier i ogłady wśród amerykańskich obywateli, „Amerykanie wraz ze swymi

\footnotetext{
63 Tamże, s. 136; H. SiENKIEwiCz, Listy, s. 452-453.

${ }^{64}$ H. Sienkiewicz, Listy, s. 170.

65 Tamże, s. 178.

${ }^{66}$ I. Rusinowa, Murzyni i Indianie, s. 142.

67 H. SienkiewICZ, Listy, s. 189-190.

${ }^{68}$ I. Rusinowa, Murzyni i Indianie, s. 144-45.

69 Tamże, s. 125-135.

70 A. Muhlstein, Manhattan, s. 140.

${ }^{71}$ H. Sienkiewicz, Listy, s. 126.

72 Tamże, s. 127, 230.
} 
przyzwyczajeniami [...] wydają się narodem barbarzyńskim" "73. Wiele miejsca poświęcił roli kobiet $\mathrm{w}$ amerykańskim społeczeństwie, a także poruszył kwestię ich emancypacji, o której tak wiele słyszał w Europie. Przyznał, że kobiety cieszą się większą niż na Starym Kontynencie swobodą oraz wielkim szacunkiem ${ }^{74}$, przy czym opinie o ich społecznym usamodzielnieniu są przesadzone: ,nigdzie nie spotykam tu takiego udziału kobiet w obowiązkach męskich, który by zasługiwał na ów rozgłos i na owe pojęcie emancypacji w Ameryce, jakie co krok napotykamy u nas w książkach poświęconych sprawie kobiecej i w ulotnych artykulikach dziennikarskich i broszurowych"75. Mimo energicznej działalności sufrażystek, prawa kobiet $\mathrm{w}$ wielu rejonach Stanów Zjednoczonych były ograniczone, zaś pełnymi prawami wyborczymi dysponowały tylko mieszkanki Wyoming (od 1869 roku) i Utah (od 1870 roku $)^{76}$.

Sienkiewicz opisał ponadto system edukacji, jako nastawiony nie na samą „naukę, ale ogólną oświatę”, i który stawiał ponad europejskim. Gwarantowana przez amerykańską konstytucję edukacja była bowiem powszechna, darmowa, oprócz umiejętności czytania i pisania oferująca także poznanie wiadomości z zakresu geografii, matematyki, nauk przyrodniczych i społecznych, przygotowanie do zawodu obywatelskiego ${ }^{77}$. Stąd też nawet przedstawiciele najniższych warstw społecznych poszczycić się mogli pewnym poziomem wykształcenia, a pisarz przyznał z tego powodu wyższość amerykańskiej cywilizacji nad europejską ${ }^{78}$.

Wśród wielu osobliwości i zwyczajów wymienionych przez Sienkiewicza, na uwagę zasługuje prawo lynchu, którego powstanie nierozerwalnie łączy się z tamtejszą historią, będące szokującym dla Europejczyka. Wymierzanie kary (od wygnania po karę śmierci) przez obywateli, z pominięciem państwowych struktur sprawiedliwości, było reakcją na przestępczość i bezprawie panujące $\mathrm{w}$ wielu miejscach dopiero powstających Stanów Zjednoczonych w XVIII i na początku wieku $\mathrm{XIX}^{79}$. Lynch był stosowany również w czasach późniejszych, na terenach Dalekiego Zachodu, gdzie władza państwowa jeszcze nie dotarła: ,jedynym prawem, zresztą z powodu uczciwości i oświaty skwaterów nigdy nie stosowanym, jest tu

73 Tamże, s. 232.

74 Tamże, 144.

75 Tamże, s. 248-257.

76 P.N. Limerick, Amerykański Zachód, s. 114; pierwsza polonijna organizacja kobieca w Stanach Zjednoczonych - Związek Polek w Ameryce (Polish Women's Alliance of America) powstała już w 1899 roku w Chicago.

77 W. Nugent, Społeczeństwo amerykańskie w latach 1850-1920, w: Historia Stanów Zjednoczonych, s. 365; H. SienKIEWICZ, Listy, s. 229.

${ }^{78}$ H. Sienkiewicz, Listy, s. 235.

79 J. CutLer, Lynch Law. An Investigation into the History of Lynching in the United States, New York 1905, s. 17-40. 
straszliwe prawo lynch, dające się chyba wyrazić w słowach: nie ząb za ząb, nie oko za oko, ale za wszelki zamach, tak przeciw osobie, jak przeciw własności, jedna tylko kara: powróz"80.

Pisarz w swoich relacjach przedstawił złożony obraz Stanów Zjednoczonych, których ze względu na ich różnorodność nie sposób jednoznacznie scharakteryzować $^{81}$. Z jego opisów wyłonił się kraj kontrastów - rozwijający się i dysponujący ośrodkami przemysłowymi na światowym poziomie, przeludniony i pusty, wielokulturowy i wieloetniczny, dziki i cywilizowany jednocześnie. To zaledwie stuletnie państwo mogło poszczycić się licznymi osiągnięciami na polu ekonomii, technologii czy polityki i konkurować z potęgami gospodarczymi, takimi jak Wielka Brytania czy Niemcy. W relacji Sienkiewicza Stany Zjednoczone jawią się jako świat zupełnie odmienny od europejskiego, mimo iż bazują na osiągnięciach Starego Kontynentu. Nowoczesne, z galopującą industrializacją i urbanizacją, bogactwami naturalnymi, postępem, kapitalizmem, ciągłym pozyskiwaniem nowych terenów oraz gwarantowaną przez konstytucję wolnością i równością przyciągały wielu przybyszów z całego świata. Niezliczone grupy etniczne, rasowe i narodowościowe wzmacniały różnorodny charakter Stanów Zjednoczonych, doprowadzając pisarza do stwierdzenia, iż „istnieje państwo, ale nie ma narodu" ${ }^{2}$. Sienkiewicz upatrywał jednak w imigracji europejskiej szans na jego dalszą rozbudowę ${ }^{83}$. Na tym polu znaczny wkład mieli właśnie Polacy, którzy w poszukiwaniu wolności i szans na lepsze życie opuszczali tereny Ojczyzny, by ciężką pracą współtworzyć wielokulturową panoramę tego kraju.

Sienkiewicz odwiedził Stany Zjednoczone w początkowej fazie powstawania amerykańskiej Polonii i mimo iż jego emigracja nie miała charakteru ekonomicznego, a on sam pochodził z wyższych warstw społeczeństwa, to relacje, które sporządził, mogą służyć rekonstrukcji sposobu widzenia i rozumienia tego kraju przez Polaków. Obraz, który wyłaniał się z jego Listów, znacznie różnił się od wizji świata znanej Europejczykowi, bez względu na to, z jakiej warstwy społecznej pochodził: „początkowo zdaje się, że tu ludzie uwzięli się, żeby we wszystkim postępować odwrotnie jak w Europie" ${ }^{"}$. Dla mas Polaków, zwłaszcza pochodzenia chłopskiego, znalezienie się w tym chaotycznym i obcym kraju musiało okazać się dużym wyzwaniem. Dodatkowymi czynnikami utrudniającymi emigrację były bariera językowa i nieznajomość tamtejszych realiów. Szczególnie istotnymi różnicami dla polskich wychodźców ze znajdującej się pod zaborami Polski mogły okazać

\footnotetext{
${ }^{80}$ H. SiENKIEwicz, Listy, s. 300.

81 Tamże, s. 596.

82 Tamże, s. 135, 541.

83 Tamże, s. 601-602.

84 Tamże, s. 233-234.
} 
się szeroko pojęte wolności gwarantowane przez amerykańską konstytucję, możliwość uczestnictwa w życiu politycznym, nieskrępowanego wyznawania własnej religii, a przede wszystkim manifestowania przynależności etnicznej i wyrażania patriotyzmu. Odmienności obejmowały również tło gospodarcze - wyjeżdżający „za chlebem” w Ameryce napotykali korzystne warunki ekonomiczne i wiele możliwości znalezienia pracy: od tych oferowanych w zakładach przemysłowych, przez rolnictwo, po kolonizację Dalekiego Zachodu i zakładanie własnych przedsiębiorstw. Stany Zjednoczone kontrastowały z państwami Starego Kontynentu także poprzez społeczny krajobraz, z szeroko pojętą równością intelektualną i obyczajową, ideami demokracji i dostępem do edukacji.

Pomimo wielu różnic pomiędzy światem europejskim a amerykańskim oraz faktu, że część z polskich imigrantów, którzy od lat 70. XIX wieku przybyli do Stanów Zjednoczonych, nie przetrwała próby ${ }^{85}$, zdecydowana ich większość zdołała odnaleźć się w nowej rzeczywistości. Masy polskich imigrantów, tak jak Sienkiewicz, musiały zatem dostrzegać potencjał tego kraju, oferującego możliwości godnego życia, rozwoju i zarobku, dzięki czemu mogła powstać tam jedna z największych diaspor polskich.

\section{BIBLIOGRAFIA}

Chicago Neighborhoods and Suburbs. A Historical Guide, red. A.D. Keating, ChicagoLondon: University of Chicago Press 2008.

CutLer J., Lynch Law. An Investigation into the History of Lynching in the United States, New York: Longmans, Green 1905.

Encyclopedia of Chicago, red. J.R. Grossman, A.D. Keating, J.L. Reiff, Chicago: University of Chicago Press 2005, wersja elektroniczna w: http://www.encyclopedia. chicagohistory.org/

Fox P., The Poles of America, New York: G.H. Doran 1922.

Historia Stanów Zjednoczonych, t. III: 1848-1917, red. W. Nugent, H. Parafianowicz, Warszawa: Wydawnictwo Naukowe PWN 1995.

KruszKa W., Historyja polska w Ameryce: początek, wzrost i rozwój dziejowy osad polskich w Północnej Ameryce (Stanach Zjednoczonych i Kanadzie), t. I, Milwaukee: Druk. Spółki Wydawniczej Kuryera 1905.

LeŚ B., Kościół w procesie asymilacji Polonii amerykańskiej, Wrocław: Zakład Narodowy im. Ossolińskich 1981.

Modrzejewska H., Memoirs and Impressions of Helena Modjeska. An Autobiography, New York: The Macmillan Company 1910.

\footnotetext{
85 Tamże, s. 442; trudności związane z emigracją Sienkiewicz opisał w noweli Za chlebem.
} 
Muhlstein A., Manhattan. Niezwykła historia Nowego Jorku od czasów Indian do roku 2000, tłum. K. Osińska-Boska, Warszawa: Państwowy Instytut Wydawniczy 1994.

NobiLis M., Sienkiewicz and the Poles in America, „Polish American Studies” 2(1945), nr 1-2.

Pacyga D.A., Chicago. A Biography, Chicago: University of Chicago Press 2009.

Poles of Chicago 1837-1937. A History of a Century of Polish Contribution to the City of Chicago, Illinois, Chicago: Polish Pageant Inc. 1937.

Sienkiewicz H., Listy z podróży do Ameryki, Warszawa: Państwowy Instytut Wydawniczy 1956.

Stasik F., Polska emigracja zarobkowa w Stanach Zjednoczonych Ameryki 1865-1914, Warszawa: Wydawnictwo Naukowe PWN 1985.

SwasteK J., Polish Travelers in Nineteenth Century United States, „Polish American Studies" 2(1945), nr 1-2.

WarYch E.B., Sienkiewicz's Sojourn in America, „Polish American Studies” 15(1958), nr 3-4.

\author{
OBRAZ STANÓW ZJEDNOCZONYCH AMERYKI \\ W LATACH SIEDEMDZIESIĄTYCH XIX WIEKU \\ W LISTACH Z PODRÓŻY DO AMERYKI HENRYKA SIENKIEWICZA
}

\title{
Streszczenie
}

Celem artykułu jest analiza obrazu Stanów Zjednoczonych, jaki Henryk Sienkiewicz zawarł w Listach z podróży do Ameryki. Pisarz odwiedził ten kraj w 1876 roku, w 100 rocznicę jego powstania, w epoce gilded age, a jego relacje ukazywały się w kilku polskich gazetach w latach 1876-1878. Obserwując nieznane dotąd miejsca i społeczeństwo, dementował stereotypy narosłe wokół Stanów na Starym Kontynencie. Z jego Listów wyłania się wizja państwa złożonego, kosmopolitycznego, rozwijającego się, pełnego wolności i przeciwieństw, jak również zjawisk obcych mentalności europejskiej. Oprócz tego, Listy z podróży do Ameryki Sienkiewicza, które zostały napisane w czasie, kiedy przybywający do Stanów masowo Polacy zaczęli tworzyć pierwsze struktury przyszłej Polonii, mogą służyć jako źródło w poznaniu ówczesnego postrzegania panoramy kraju przez Polaków.

Słowa kluczowe: historia Stanów Zjednoczonych; wiek pozłacany; Polacy w Ameryce; polska emigracja; Henryk Sienkiewicz 
THE IMAGE OF UNITED STATES OF AMERICA IN 1870S

IN HENRYK SIENKIEWICZ'S LISTY Z PODRÓŻY DO AMERYKI

\section{Su m mary}

The article aims to analyze the image of United States of America, in Henryk Sienkiewicz's Listy z podróży do Ameryki. The novelist visited this country in 1876, in centennial anniversary of its Independence, during gilded age, and his accounts were published in several Polish newspapers in 1876-1878. Observing unknown country and society, the Novelist denied stereotypes about United States popular in the Old Continent. The image of complex, cosmopolitan, developing, full of liberties, and contradictions, as well as phenomena unfamiliar to European mentality was shown in his Listy.

Moreover, Sienkiewicz's Listy which were written when Poles who had came to United States started to create first structures of future Polonia, can be consider as a source in researching of perceiving this country by Poles of that time.

Key words: history of United States; gilded age; Poles in America; Polish emigration; Henryk Sienkiewicz 